\title{
Proposed Amendments to the Bylaws of the American Osteopathic Association
}

At its 1989 Interim and its 1990 Midyear meetings, the AOA Board of Trustees, upon recommendation of the Committee on Membership, adopted the following proposed amendments to the AOA Bylaws. The amendments will be voted on by the House of Delegates at its July, 1990 Annual Meeting:

(old material in italics; new material in capitals)

Article II-Membership, Section 2-Membership Requirements.

a. Applicants for Regular Membership. An applicant for regular membership in this Association shall be a graduate of a college of osteopathy OSTEOPATHIC MEDICINE approved by the American Osteopathic Association and shall be eligible for licensure as an osteopathic physicians and/ or surgeon or shall be in a training program approved by the Association which is a prerequisite for his licensure. APPLICATION SHALL BE MADE ON THE PRESCRIBED FORM AND SHALL BE ACCOMPANIED BY PAYMENT OF THE APPROPRIATE DUES AMOUNT.

UNLESSSPECIFICALLY NOTED, APPLICANTS WHOSE COMPLETED APPLICATION AND PAYMENT OF APPROPRIATE DUES HAVE BEEN RECEIVED AND PROCESSED SHALL BE ENROLLED AS REGULAR MEMBERS.

APPLICANTS WHOSE MEMBERSHIP IN THIS ASSOCIATION HAS PREVIOUSLY BEEN WITHDRAWN FOR REASONS OTHER THAN FAILURE TO MEET CME REQUIREMENTS OR NON-PAYMENT OF DUES OR APPLICANTS WHO HAVE PREVIOUSLY BEEN CONVICTED OF A FELONY OFFENSE OR WHOSE LICENSE TO PRACTICE HAS AT ANY TIME BEEN REVOKED SHALL BE FURTHER REQUIRED TO OBTAIN He shall make application upon a prescribed form with the endorsement of the secretary of the divisional society in the state, province or foreign country in which the applicant resides (or with the endorsement of the secretary of the uniformed services divisional society in the case of applicants currently serving in the uniformed services of the United States), or, lacking this endorsement, an applicant who is in good standing in his community shall provide letters of recommendation from three members of the Association AND PROVIDE A PERSONAL WRITTEN STATEMENT AS TO WHY MEMBERSHIP IN THE ASSOCIATION SHOULD BE EXTENDED OR RESTORED. SUCH INFORMATION AND APPLICATION SHALL BE CAREFULLY REVIEWED BY THE COMMITTEE ON MEMBERSHIP WHICH SHALL MAKE APPROPRIATE RECOMMENDATION FOR REINSTATEMENT TO THE BOARD OF TRUSTEES.

APPLICANTS WHOSE LICENSE TO PRACTICE IS REVOKED OR SUSPENDED OR WHO IS CURRENTLY SERVING A SENTENCE FOR CONVICTION OF A FELONY OFFENSE SHALL NOT BE CONSIDERED ELIGIBLE FOR MEMBERSHIP IN THIS ASSOCIATION.

The application of a new graduate received within one year following his graduation shall be endorsed by the dean of the College from which the applicant was graduated.

Applications shall be accompanied by a payment of the full amount of annual dues except that applications received after the first half of the fiscal 
year from those whose dues rates are other than the training program rate shall be accompanied by an amount equal to one half of annual dues. Upon receipt of a completed application and payment of the appropriate dues amount, the Executive Director shall enroll the applicant as a regular member subject to the satisfactory completion of the application process. The name of the applicant shall be published in the JOURNAL OF THE AMERICAN OSTEOPATHIC ASSOCIATION. If objections are received within 30 days, the Board of Trustees shall make full investigation and take such action as its findings warrant.

Upon recommendation of his divisional society and the AOA Committee on Membership, an applicant who does not meet the requirements as set forth in the Bylaws may, by individual consideration, be granted membership by the Board of Trustees.

Explanatory Statement: The proposed changes to the Bylaws will bring this section into conformity with other sections and facilitate the more timely readmission of former members.

Article II-Membership, Section 2-Membership Requirements.

d. Associate Member. By specific action of the Board of Trustees, or its Executive Committee, associate memberships may be granted to teaching, research, administrative, or executive employees of approved osteopathic colleges or of accredited osteopathic hospitals, and to administrative employees of this Association or of affiliated organizations or of divisional societies, excepting doctors of osteopathy and students in osteopathic colleges.

D. ASSOCIATE MEMBER. BY SPECIFIC ACTION OF THE BOARD OF TRUSTEES, OR ITS EXECUTIVE COMMITTEE, ASSOCIATE MEMBERSHIPS MAY BE GRANTED TO THE FOLLOWING:

GRADUATES OF ACCREDITED SCHOOLS OF MEDICINE, DENTISTRY AND PODIATRY HOLDING TEACHING, RESEARCH OR ADMINISTRATIVE POSITIONS IN AOA APPROVED HOSPITALS AND COLLEGES OR WHO PRACTICE JOINTLY WITH REGULAR MEMBERS OF THIS ASSOCIATION.

DOCTORS OF PHILOSOPHY OR EDUCATION AND OTHER NONDOCTORAL PERSONNEL HOLDING TEACHING, RESEARCH OR ADMINISTRATIVE POSITIONS IN AOA APPROVED HOSPITALS AND COLLEGES.

ADMINISTRATIVE EMPLOYEES OF THIS ASSOCIATION, AFFILIATED ORGANIZATIONS AND DIVISIONAL SOCIETIES.

ANY OTHER PROFESSIONALS AS DETERMINED BY THE BOARD OF TRUSTEES, EXCEPTING DOCTORS OF OSTEOPATHY AND STUDENTS IN OSTEOPATHIC COLLEGES.

Such associate members shall not be required to pay dues AND or assessments AS DETERMINED BY THESE BYLAWS. They shall have the right to subscribe to RECEIVE A COMPLIMENTARY SUBSCRIPTION TO the Association's publications at a rate to be fixed by the Board. AND SHALL BE ELIGIBLE FOR SUCH BENEFITS AS ARE PERIODICALLY ESTABLISHED BY THE BOARD OF TRUSTEES.

Associate members shall not be eligible FOR to membership in the House of Delegates or the Board of Trustees, or to hold any elective offices of this Association. Special listing in the YEARBOOK AND DIRECTORY shall be provided. 
ARTICLE III-Dues and Assessments, Section 2-Dues Rates

a. Regular Members. The annual dues of regular members of the Association shall be three hundred fifteen dollars (\$315) THREE HUNDRED NINETY DOLLARS (\$390), effective in the 1989/90 fiscal years. Forty dollars $(\$ 40)$ of the annual dues of regular members shall be placed in a restricted, interest bearing account for a period of ten (10) years, identified as the "Endowment for Osteopathic Research," dedicated to the furtherance of research in the profession. Ninety (90) percent of the interest earnings from this account may be utilized and the remainder of the interest accrues to the corpus of the fund. The available earnings shall be utilized by the Bureau of Research of this Association to support the development of qualified clinical investigators in osteopathic philosophy, principles and practice and to support targeted research on osteopathic philosophy, principles and practice.

Explanatory Statement: Membership dues have not been increased since 1980 for operating funding, therefore the Board of Trustees is recommending an increase of $\$ 75$ ( $\$ 315$ to $\$ 390$ ), which includes $\$ 40$ for research.

(New Section)

H. ASSOCIATE MEMBERS. THE ANNUAL DUES OF ASSOCIATE MEMBERS OF THE ASSOCIATION SHALL BE SEVENTY-FIVE DOLLARS (\$75).

\section{Proposed Amendment to the AOA Constitution}

In July, 1989, the House of Delegates adopted the following proposed amendments to the Constitution of the American Osteopathic Association to be submitted to a vote pursuant to the terms of the Constitution and Bylaws at the 1990 Annual Meeting:

(old material in italics; new material in capitals)

Article VIII-Board of Trustees and Executive Committee Section 1-Board of Trustees.

The Board of Trustees of this Association shall consist of the President, President-elect, the Past Presidents for the preceding two years, First Vice President, Second Vice President, Third Vice President, and of fifteen EIGHTEEN other members, five SIX of whom shall be elected annually by the House of Delegates to serve for three years. The Board shall be the administrative and executive body of the Association and perform such other duties as are provided by the Bylaws.

Explanatory Statement: The Board of Trustees' intention in submitting this amendment is to facilitate representation of additional states to the Board. 